\title{
Anticancer, Antioxidant and Immunomodulator Ingredients of Halwa-i Gheekwar: A Review
}

\section{Bilal Ahmad ${ }^{1 *}$, Quddusi N ${ }^{1}$, Usama Akram² ${ }^{2}$ Mohammad Fazil ${ }^{3}$ and AA $\mathrm{Khan}^{4}$}

${ }^{1}$ Research Officer, Scientist-III, Hakim Ajmal Khan Institute for Literary and Historical Research in Unani Medicine, (CCRUM), New Delhi, India

${ }^{2}$ Research Officer, Scientist-I, Hakim Ajmal Khan Institute for Literary and Historical Research in Unani Medicine, (CCRUM), New Delhi, India

${ }^{3}$ Head of the Institute, Hakim Ajmal Khan Institute for Literary and Historical Research in Unani Medicine, (CCRUM), New Delhi, India

${ }^{4}$ Director General, CCRUM, Ministry of AYUSH, New Delhi, India

*Corresponding Author: Bilal Ahmad, Research Officer, Scientist-III, Hakim Ajmal Khan Institute for Literary and Historical Research in Unani Medicine, (CCRUM),

New Delhi, India.
Received: July 16, 2020

Published: September 16, 2020

(C) All rights are reserved by Bilal Ahmad., et al.

\begin{abstract}
Halwa-i Gheekwar (HG) is a polyherbal formulation used in various diseases for preventive and curative purposes. It is prepared by adding herbal drugs to the base (Qiwam) which contains sugar. The formulation has been described to possess aphrodisiac, nervine tonic and laxative properties and is used to treat joint pain, lumbago, cough and dyspnoea. Single drugs, used as ingredients of HG include Withania somnifera, Elettaria cardamomum, Curcuma amada, Euryale ferox, Cinnamomum cassia, Orchis mascula, Alpinia galangal, Cinnamomum zeylanicum, Zingiber officinale, Asparagus racemosus, Syzygium aromaticum, Saussurea lappa, Celastrus peniculatus, Rubia cordifolia, Juglans regia, Prunus amygdalus, Cocos nucifera, Chlorophytum borivilianum, Aloe vera, Phoenix dactylifera, etc., Cotemporary studies on these single drugs demonstrate their activities as anticancer, antioxidant and immunomodulator agents. This review article has discussed the medicinal importance of HG in the light of recent studies on its individual ingredients.
\end{abstract}

Keywords: Halwa; Free Radicals; Anticancer; Antioxidant; Immunomodulator

\section{Introduction}

Cancer is a group of diseases characterized by the uncontrolled growth and spread of abnormal cells. Its uncontrolled spread may result in death. According to the information available with World Cancer Research Fund International there were an estimated 14.1 million cancer cases around the world in 2012, of these 7.4 million cases were in men and 6.7 million in women. This number is expected to increase to 24 million by 2035 . Lung cancer was the most common cancer worldwide in men contributing nearly $12.3 \%$ of the total number of new cases diagnosed in 2018. The top three, lung, prostate and colorectal cancers, contributed nearly $30.4 \%$ of all cancers (excluding non-melanoma skin cancer). Other common cancer contributing more than $5 \%$ was stomach. Breast cancer was the most common cancer worldwide in women contributing more than $12.3 \%$ of the total number of new cases diagnosed in 2018. Cervical cancer also contributed nearly $3.3 \%$ of all cancers (excluding non-melanoma skin cancer) [1].

In the last two decades, advances have been made in cancer treatment; however, the success rate still remains poor. Current 
treatment choices are accompanied by adverse effects, drug resistance, and cancer recurrence. Therefore, there is always a scope for new therapeutic options.

In recent years, AYUSH systems including Unani System of Medicine (USM) has been gaining interest in the scientific community and a greater stress has been given towards the studies on traditional systems that deal with cancer management and help to overcome the side effects of conventional treatment including chemotherapy and radiotherapy.

The classical literature of USM describes the Cancer as Sartan and defines it as a painful, dark coloured, hard, Sawdawi (Melancholic) swelling [2] with many roots [3], affecting any organ (external/internal) of the body $[4,5]$.

Unani physicians believe that cancer is caused by accumulation of Sawda (Black bile), produced due to Ihtiraq (burning/oxidation) of humours, in the body. This kind of black bile is known as Sawda Muhtaraq (Burnt/oxidized black bile) [2]. According to Ibn Sina, it is caused by the black bile, produced by burning/oxidation of yellow bile [6].

Razi has enlisted the causes of excessive production/accumulation of black bile in the body and these are, inability of spleen to absorb black bile, excessive heat in the liver and intake of diets helping in excessive production of Dam Sawdawi (Melancholic sanguine) [7].

The objectives of treatment with Unani drugs and regimens are:

- $\quad$ Prevention for those who are prone to cancer e.g. family history, melancholic temperament, lifestyle not in accordance with the prescribed rules (Asbab Sitta Zarooriyya).

- Treatment of cancer through various means such as evacuation of causative humour from the body, administration of Muqawwiyat (Tonics) i.e. antioxidant and immunomodulator drugs mentioned in Unani classical literature, etc.

- $\quad$ Reduction of side effects of chemotherapy or radiation therapy.

Cancer can be treated through evacuation of morbid matter form the body, making the consistency of sanguine thin [8], and extinguishing the increased heat of liver $[9,10]$.
In addition, the present Unani physicians are also utilizing the unique approach of their System of Medicine to tone up the organs and the immune system which has shown much utility in improving the quality of life of patients suffering from chronic and some of the intractable diseases including Cancer. Many of the Muqawwiyat (Tonics) mentioned in Unani literature, possess antioxidant and immunomodulatory actions. These drugs when administered in single or compound form may serve as biological response modifiers by activating, increasing and restoring the reactivity of immunological effector mechanisms that are involved in resistance to tumor growth and metastasis and may assist in coping the oxidative stress responsible for many pathological conditions, including cancer.

The compound formulation Halwa-i Gheekwar is frequently used by Unani physicians for prophylactic and therapeutic purposes. It contains various single Unani drugs, which have been reported to possess anticancerous, antioxidant and immunomodulatory activities. Therefore, the oral administration of Halwa-i Gheekwar may play an important role in prevention and treatment of cancer. It may also help to reduce the side effects of chemotherapy or radiation therapy and improve the quality of life of cancer patients.

The studies carried out on different ingredients of Halwa-i Gheekwar are as follows:

\begin{tabular}{|c|c|c|c|}
\hline $\begin{array}{c}\text { S. } \\
\text { No. }\end{array}$ & Ingredient & Activity & References \\
\hline \multirow[t]{3}{*}{1} & \multirow{3}{*}{$\begin{array}{c}\text { Asgand Nagori } \\
\text { (Withania somnifera } \\
\text { Dunal.) }\end{array}$} & Anticancer & {$[11]$} \\
\hline & & Antioxidant & {$[12]$} \\
\hline & & Immunomodulatory & [13] \\
\hline \multirow[t]{3}{*}{2} & \multirow{3}{*}{$\begin{array}{l}\text { Ilaichi Khurd (Elet- } \\
\text { taria cardamomum } \\
\text { Maton.) }\end{array}$} & Anticancer & {$[14]$} \\
\hline & & Antioxidant & {$[15]$} \\
\hline & & Immunomodulatory & [16] \\
\hline \multirow[t]{3}{*}{3} & \multirow{3}{*}{$\begin{array}{c}\text { Amba Haldi (Curcu- } \\
\text { ma amada Roxb.) }\end{array}$} & Anticancer & {$[17,18]$} \\
\hline & & Antioxidant & [19] \\
\hline & & Immunomodulatory & {$[20]$} \\
\hline \multirow[t]{2}{*}{4} & \multirow{2}{*}{$\begin{array}{l}\text { Talmakhana (Euryale } \\
\text { ferox Salisb.) }\end{array}$} & Antioxidant & {$[21]$} \\
\hline & & Immunomodulatory & {$[22]$} \\
\hline \multirow[t]{3}{*}{5} & \multirow{3}{*}{$\begin{array}{l}\text { Taj (Cinnamomum } \\
\text { cassia Blume) }\end{array}$} & Anticancer & {$[23]$} \\
\hline & & Antioxidant & {$[24]$} \\
\hline & & Immunomodulatory & {$[25]$} \\
\hline
\end{tabular}




\begin{tabular}{|c|c|c|c|}
\hline 6 & $\begin{array}{l}\text { Salab Misri (Orchis } \\
\text { mascula Linn.) }\end{array}$ & Antioxidant & {$[26]$} \\
\hline \multirow[t]{3}{*}{7} & \multirow{3}{*}{$\begin{array}{l}\text { Khulanjan (Alpinia } \\
\text { galanga Linn.) }\end{array}$} & Anticancer & {$[27]$} \\
\hline & & Antioxidant & {$[28]$} \\
\hline & & Immunomodulatory & {$[29]$} \\
\hline \multirow[t]{3}{*}{8} & \multirow{3}{*}{$\begin{array}{c}\text { Darchini (Cinnamo- } \\
\text { mum zeylanicum } \\
\text { Blunc.) }\end{array}$} & Anticancer & {$[30]$} \\
\hline & & Antioxidant & [31] \\
\hline & & Immunomodulatory & {$[32]$} \\
\hline \multirow[t]{3}{*}{9} & \multirow{3}{*}{$\begin{array}{c}\text { Zanjabeel (Zingiber } \\
\text { officinale Rosc.) }\end{array}$} & Anticancer & [33] \\
\hline & & Antioxidant & {$[34]$} \\
\hline & & Immunomodulatory & [35] \\
\hline \multirow[t]{3}{*}{10} & \multirow{3}{*}{$\begin{array}{l}\text { Satawar (Asparagus } \\
\text { racemosus Willd.) }\end{array}$} & Anticancer & {$[36]$} \\
\hline & & Antioxidant & [37] \\
\hline & & Immunomodulatory & {$[38]$} \\
\hline \multirow[t]{3}{*}{11} & \multirow{3}{*}{$\begin{array}{c}\text { Qaranful (Syzygium } \\
\text { aromaticum Merr } \\
\text { and L.M. Perry) }\end{array}$} & Anticancer & [39] \\
\hline & & Antioxidant & [40] \\
\hline & & Immunomodulatory & [41] \\
\hline \multirow[t]{3}{*}{12} & \multirow{3}{*}{$\begin{array}{l}\text { Qust Shireen (Sau- } \\
\text { ssurea lappa C.B } \\
\text { Clarke) }\end{array}$} & Anticancer & {$[42]$} \\
\hline & & Antioxidant & {$[43]$} \\
\hline & & Immunomodulatory & {$[44]$} \\
\hline \multirow[t]{2}{*}{13} & \multirow[t]{2}{*}{$\begin{array}{c}\text { Malkangni (Celastrus } \\
\text { peniculatus Willd.) }\end{array}$} & Antioxidant & {$[45]$} \\
\hline & & Immunomodulatory & [46] \\
\hline \multirow[t]{3}{*}{14} & \multirow{3}{*}{$\begin{array}{l}\text { Majeeth (Rubia cor- } \\
\text { difolia Linn.) }\end{array}$} & Anticancer & {$[47]$} \\
\hline & & Antioxidant & [48] \\
\hline & & Immunomodulatory & [49] \\
\hline \multirow[t]{2}{*}{15} & \multirow{2}{*}{$\begin{array}{l}\text { Maghz Akhrot ( Jug- } \\
\text { lans regia Linn.) }\end{array}$} & Anticancer & {$[50]$} \\
\hline & & Antioxidant & {$[51]$} \\
\hline \multirow[t]{3}{*}{16} & \multirow{3}{*}{$\begin{array}{c}\text { Maghz Badam } \\
\text { Shireen (Prunus } \\
\text { amygdalus Batsch.) }\end{array}$} & Anticancer & {$[52]$} \\
\hline & & Antioxidant & {$[53]$} \\
\hline & & Immunomodulatory & {$[54]$} \\
\hline \multirow[t]{3}{*}{17} & \multirow{3}{*}{$\begin{array}{c}\text { Maghz Narjeel (Cocos } \\
\text { nucifera Linn.) }\end{array}$} & Anticancer & {$[55]$} \\
\hline & & Antioxidant & {$[56]$} \\
\hline & & Immunomodulatory & [57] \\
\hline \multirow[t]{3}{*}{18} & \multirow{3}{*}{$\begin{array}{l}\text { Musli Safed (Chloro- } \\
\text { phytum borivilianum } \\
\text { Baker.) }\end{array}$} & Anticancer & {$[58]$} \\
\hline & & Antioxidant & {$[59]$} \\
\hline & & Immunomodulatory & {$[60]$} \\
\hline \multirow[t]{2}{*}{19} & \multirow{2}{*}{$\begin{array}{l}\text { Musli Sainbal (Bom- } \\
\quad \text { bax ceiba Linn.) }\end{array}$} & Antioxidant & {$[61]$} \\
\hline & & Immunomodulatory & {$[62]$} \\
\hline
\end{tabular}

\begin{tabular}{|c|c|c|c|}
\hline 20 & \multirow{2}{*}{$\begin{array}{c}\text { Gheekwar Sabz (Aloe } \\
\text { vera Linn.) }\end{array}$} & Anticancer & {$[63]$} \\
\cline { 3 - 4 } & & Antioxidant & {$[64]$} \\
\cline { 3 - 4 } & & Immunomodulatory & {$[65]$} \\
\hline 21 & \multirow{2}{*}{$\begin{array}{c}\text { Khajoor (Phoenix } \\
\text { dactylifera Linn.) }\end{array}$} & Anticancer & {$[66]$} \\
\cline { 3 - 4 } & & Antioxidant & {$[67]$} \\
\cline { 3 - 4 } & & Immunomodulatory & {$[68]$} \\
\hline
\end{tabular}

Table

\section{Conclusion}

The compound formulation Halwa-i Gheekwar is frequently used by Unani physicians for prophylactic and therapeutic purposes. It contains various single Unani drugs, which have been reported to possess anticancerous, antioxidant and immunomodulatory activities. Therefore, the oral administration of Halwa-i Gheekwar may play an important role in prevention and treatment of cancer. It may also help to reduce the side effects of chemotherapy or radiation therapy and improve the quality of life of cancer patients.

\section{Bibliography}

1. https://www.wcrf.org/dietandcancer/cancer-trends/worldwide-cancer-data

2. Khan M A. Iksir-i A‘zam. Vol. IV. Lucknow: Matba‘ Nami Munshi Naval Kishor (1906): 308-312.

3. Razi Muhammad b. Zakariyya. Kitab al-Manssori (Urdu Translation). New Delhi. CCRUM (1991): 266-267.

4. Majoosi 'Ali b. 'Abbas. Kamil al-Sana'a al-Tibbiyya. Vol. II. New Delhi. CCRUM (2005): 467-468.

5. Ibn al-Quff. Kitab al-'Umda fi al-Jaraha. Vol. II. Hyderabad India. Da'ira al-Ma'arif al-Usmaniya 1356H: 43-48.

6. Ibn Sina. al-Qānūn fi'l-Tibb. Vol. IV. New Delhi. Jamia Hamdard 1417 H: 195-197.

7. Razi Muhammad b. Zakariyya. Kitab al-Hawi fi al-Tibb. Vol. XII. Hyderabad India. Da'ira al-Ma'arif al-Usmaniya (1962): 01-24.

8. Nafīs b. 'Iwaz. Sharah al-Asbab wa-al-'Alamat. Vol. II. Lucknow: Matba' Nami Munshi Naval Kishor 1326 H: 205-207.

9. Arzani M A. Tibb-i Akbar. Vol. II. Lucknow: Matba' Nami Munshi Naval Kishor (1880): 358-359. 
10. Khan M A. Rumooz-i A'zam. Vol. II. New Delhi. CCRUM (2006): 343-344.

11. Rai M., et al. "Anticancer activities of Withania somnifera: Current research, formulations, and future perspectives". Pharmaceutical Biology 54.2 (2016): 189-197.

12. Abdul Qaiyum Ansari., et al. "Extraction and determination of antioxidant activity of Withania somnifera Dunal". European Journal of Experimental Biology 3.5 (2013): 502-507.

13. Davis L and Kuttan G. "Immunomodulatory activity of Withania somnifera". Journal of Ethnopharmacology 71 (2000): 193200.

14. Majdalawieh AF and Carr RI. "In vitro investigation of the potential immunomodulatory and anti-cancer activities of black pepper (Piper nigrum) and cardamom (Elettaria cardamomum)". Journal of Medicinal Food 13.2 (2010): 371-381.

15. Neelam Jain., et al. "Evaluation of Antioxidant Properties and Total Phenolic Content of Medicinal Plants Used In Diet Therapy During Postpartum Healthcare In Rajasthan". International Journal of Pharmacy and Pharmaceutical Sciences 3.3 (2001): 248-253.

16. Anuradha Vaidya and Maitreyi Rathod. "An in vitro study of the immunomodulatory effects of Piper nigrum (black pepper) and Elettaria cardamomum (cardamom) extracts using a murine macrophage cell line". American International Journal of Research in Formal, Applied and Natural Sciences 8.1 (2014): 18-27.

17. T Muthu kumar., et al. "Anticancer and antioxidant activity of Curcuma zedoaria and Curcuma amada rhizome extracts". Journal of Academia and Industrial Research (JAIR) 1.2 (2012): 91-96.

18. Cheppail Ramachandran., et al. "Anticancer Potential and Mechanism of Action of Mango Ginger (Curcuma amada Roxb.) Supercritical CO2 Extract in Human Glioblastoma Cells". Journal of Evidence-Based Complementary and Alternative Medicine 20.2 (2015): 109-119.
19. RS Policegoudra., et al. "Biochemical changes and antioxidant activity of mango ginger (Curcuma amada Roxb.) rhizomes during postharvest storage at different temperatures". Postharvest Biology and Technology 46.2 (2007): 189-194.

20. Manvendra Singh Karchuli and Debasish Pradhan. "Curcuma amada Roxb. rhizome extract modulates cellular and humoral immune system". Pharmacologyonline 3 (2011): 947-952.

21. Lee SE., et al. "Antioxidant activity of extracts from Euryale ferox seed". Experimental and Molecular Medicine 34.2 (2002): 100-106.

22. Anju Puri R., et al. "Immunostimulant activity of dry fruits and plant materials used in Indian traditional medical system for mothers after child birth and invalids". Journal of Ethnopharmacology 71 (2000): 89-92.

23. Lee., et al. "Cytotoxic and Mutagenic Effects of Cinnamomum cassia Bark-Derived Materials". Journal of Microbiology and Biotechnology 14.6 (2004): 1176-1181.

24. Lin CC., et al. "Antioxidant activity of Cinnamomum cassia". Phototherapy Research 17.7 (2004): 726-730.

25. Junfen Zeng., et al. "A New Phenolic Glycoside from the Barks of Cinnamomum cassia”. Molecules 19 (2004): 17727-17734.

26. Pahuja M., et al. "Anticonvulsant and antioxidative activity of hydroalcoholic extract of tuber of Orchis mascula in pentylenetetrazole and maximal electroshock induced seizures in rats". Journal of Ethnopharmacology 142.1 (2012): 23-27.

27. Saeed Samarghandian., et al. "Antiproliferative activity and induction of apoptotic by ethanolic extract of Alpinia galanga rhizhome in human breast carcinoma cell line". BMC Complementary and Alternative Medicine 14 (2014): 192.

28. LF Wong., et al. "Antioxidant and antimicrobial activities of some alpina species". Journal of Food Biochemistry 33.6 (2009): 835-851.

29. Ye Ying and Li BaoAn. "1'S-1'-Acetoxychavicol acetate isolated from Alpinia galanga inhibits human immunodeficiency virus type 1 replication by blocking Rev transport". Journal of General Virology 87.7 (2006): 2047-2053. 
30. Sobhy Hassab El-Nabi., et al. "The Apoptotic Properties of Cinnamomum Zeylanicum and Cymbopogon Citratus on Human Hepatocellular Carcinoma Cell Line (Hepg2)". EJPMR 3.9 (2016): 44-48.

31. Mancini-Filho J., et al. "Antioxidant activity of cinnamon (Cinnamomum Zeylanicum, Breyne) extracts". Bollettino Chimico Farmaceutico 137.11 (1998): 443-447.

32. Samir Ramchandra Niphade., et al. "Immunomodulatory activity of Cinnamomum zeylanicum bark". Pharmaceutical Biology 47.12 (2009): 1168-1173.

33. Jeong CH., et al. " [6]-Gingerol suppresses colon cancer growth by targeting leukotriene A4 hydrolase". Cancer Research 69.13 (2009): 5584-5591.

34. Höferl M., et al. "Composition and Comprehensive Antioxidant Activity of Ginger (Zingiber officinale) Essential Oil from Ecuador". Natural Product Communications 10.6 (2015): 10851090.

35. Carrasco FR., et al. "Immunomodulatory activity of Zingiber officinale Roscoe, Salvia officinalis L. and Syzygium aromaticum L. essential oils: evidence for humor- and cell-mediated responses". Journal of Pharmacy and Pharmacology 61.7 (2009): 961-967.

36. Shankar K., et al. "Shatavarins (containing Shatavarin IV) with anticancer activity from the roots of Asparagus racemosus". Indian Journal of Pharmacology 44.6 (2012): 732-736.

37. Lalana Kongkaneramit., et al. "Antioxidant activity and antiapoptotic effect of Asparagus racemosus root extracts in human lung epithelial H460 cells". Experimental and Therapeutic Medicine 2.1 (2011): 143-148.

38. Gautam M., et al. "Immunomodulatory activity of Asparagus racemosus on systemic Th1/Th2 immunity: implications for immunoadjuvant potential". Journal of Ethnopharmacology 121.2 (2009): 241-247.

39. Dwivedi V., et al. "Comparative anticancer potential of clove (Syzygium aromaticum)--an Indian spice--against cancer cell lines of various anatomical origin". Asian Pacific Journal of Cancer Prevention 12.8 (2011): 1989-1993.
40. Baghshahi H., et al. "Antioxidant effects of clove bud (Syzygium aromaticum) extract used with different extenders on ram spermatozoa during cryopreservation". Cryobiology 69.3 (2014): 482-487.

41. Shaghayegh Pishkhan., et al. "Immunomodulatory effects of clove (Syzygium aromaticum) constituents on macrophages: Invitro evaluations of aqueous and ethanolic components". Journal of Immunotoxicology 12.2 (2015): 124-131.

42. Moon SM., et al. "Anticancer activity of Saussurea lappa extract by apoptotic pathway in KB human oral cancer cells". Pharmaceutical Biology 51.11 (2013): 1372-1377.

43. Kyung-Mi Chang., et al. "Anti-oxidant Activity of Saussurea lappa C.B. Clarke Roots". Preventive Nutrition and Food Science 17.4 (2012): 306-309.

44. Kulkarni S and Desai S. "Immunostimulant activity of inulin isolated from Saussurea lappa roots". Indian Journal of Pharmaceutical Sciences 63.4 (2001): 292-294.

45. Kumar MH and Gupta YK. "Antioxidant property of Celastrus paniculatus willd: A possible mechanism in enhancing cognition". Phytomedicine 9 (2002): 302-311.

46. Kallakunta Ruth Salomi., et al. "Evaluation of immunomodulatory activity of petroleum ether extract of seeds of Celastrus paniculatus". Der Pharmacia Lettre 3.5 (2011): 87-93.

47. Patel., et al. "Potent antitumor activity of Rubia cordifolia". International Journal of Phytomedicine 2 (2010): 44-46.

48. AA Joharapurkar., et al. "In vivo evaluation of antioxidant activity of alcoholic extract of Rubia cordifolia linn. and its influence on ethanol-induced immunosuppression". Indian Journal of Pharmacology 35 (2003): 232-236.

49. Lodi S., et al. "The protective effect of Rubia cordifolia against lead nitrate-induced immune response impairment and kidney oxidative damage". Indian Journal of Pharmacology 43.4 (2011): 441-444.

50. Zhang., et al. "Activity guided isolation and modification of juglone from Juglans regia as potent cytotoxic agent against lung cancer cell lines". BMC Complementary and Alternative Medicine 15 (2015): 396. 
51. AGP Samaranayaka., et al. "Antioxidant activity of English walnut (Juglans regia L.)". Journal of Food Lipids 15 (2008): 384397.

52. Davis PA and Iwahashi CK. "Whole almonds and almond fractions reduce aberrant crypt foci in a rat model of colon carcinogenesis". Cancer Letter 165.1 (2001): 27-33.

53. Wijeratne SS., et al. "Antioxidant polyphenols in almond and its coproducts". Journal of Agricultural and Food Chemistry 54.2 (2006): 312-318.

54. Puri A., et al. "Immunostimulant activity of dry fruits and plant materials used in indian traditional medical system for mothers after child birth and invalids". Journal of Ethnopharmacology 71 (2000): 89-92.

55. Koschek., et al. "The husk fiber of Cocos nucifera L. (Palmae) is a source of anti-neoplastic activity". Brazilian Journal of Medical and Biological Research 40 (2000): 1339-1343.

56. Naskar., et al. "Comparative in vitro antioxidant activity of different parts of Cocos nucifera (Linn.) on reactive oxygen and nitrogen species". International Journal of Pharmacy and Pharmaceutical Sciences 3 (2011): 104-107.

57. A Geo Vigila and X Baskaran. "Immunomodulatory Effect of Coconut Protein on Cyclophosphamide Induced Immune Suppressed Swiss Albino Mice". Ethnobotanical Leaflets 12 (2008): 1206-1212.

58. Kumar M., et al. "Anti-tumour, anti-mutagenic and chemomodulatory potential of Chlorophytum borivilianum". Asian Pacific Journal of Cancer Prevention 11.2 (2010): 327-334.

59. Abhishek Niranjan., et al. "Phytochemical and Antioxidant Potential of Chlorophytum borivilianum (Safed musli) Under Different Agronomical Management Practices". International Journal of Applied Agricultural Research 4.1 (2009): 47-55.

60. Mayank Thakur., et al. "Immunomodulatory Activity of Chlorophytum borivilianum Sant. F". Evidence-Based Complementary and Alternative Medicine 4.4 (2007): 419-423.

61. Sharma KR., et al. "In Vitro Free Radical Scavenging Activity of Methanol Extracts of Some Selected Medicinal Plants of Nepal". Austin Journal of Biotechnology and Bioengineering 2.1 (2015): 1035.
62. Ashish Mishra., et al. "Evaluation of immunomodulatory activity of polysacchride fraction of Inula racemosa, Bombax ceiba and Allium sativum". IJPSR 7.9 (2016): 3749-3755.

63. El-Shemy HA., et al. "Antitumor properties and modulation of antioxidant enzymes' activity by Aloe vera leaf active principles isolated via supercritical carbon dioxide extraction". Current Medicinal Chemistry 17.2 (2010): 129-138.

64. Hu Y., et al. "Evaluation of antioxidant potential of aloe vera (Aloe barbadensis miller) extracts". Journal of Agricultural and Food Chemistry 51.26 (2003): 7788-7791.

65. Im SA., et al. "In vivo evidence of the immunomodulatory activity of orally administered Aloe vera gel". Archives of Pharmacal Research 33.3 (2010): 451-456.

66. Omar Ishurda and John F Kennedy. "The anti-cancer activity of polysaccharide prepared from Libyan dates (Phoenix dactylifera L.)". Carbohydrate Polymers 59 (2005): 531-535.

67. Vayalil PK. "Antioxidant and antimutagenic properties of aqueous extract of date fruit (Phoenix dactylifera L. Arecaceae)". Journal of Agricultural and Food Chemistry 50 (2002): 610617.

68. Kehili Houssem Eddine., et al. "Immunostimulatory activity of Phoenix dactylifera". International Journal of Pharmacy and Pharmaceutical Sciences 6.3 (2014): 73-76.

\section{Assets from publication with us}

- Prompt Acknowledgement after receiving the article

- Thorough Double blinded peer review

- Rapid Publication

- Issue of Publication Certificate

- High visibility of your Published work

Website: www.actascientific.com/

Submit Article: www.actascientific.com/submission.php Email us: editor@actascientific.com

Contact us: +919182824667 